\title{
Editor's Note: Historiography at the Margins
}

This issue of $D R J$ focuses on seminal soloists of the first half of the twentieth century-Isadora Duncan, Tórtola Valencia, Anna Pavlova, and Uday Shankar. Scholars weigh the cosmopolitan status of these international dance stars against their local, cross-cultural, or, what we might call vernacular engagements with both movement and culture, which until now have been all but eclipsed or relegated to the margins of historiography; they privilege the role media, advertising, film, autobiography, and dance history itself have played in the fashioning of a cosmopolitan identity, even as the artist's own experience of travel, collecting, memoirs, local politics, film making in one instance, and semi-private performances in another suggest a more variegated and difficult reality, local and sometimes subcultural interpretive communities, and decidedly less universalizing choreographic messages than traditionally assumed. The underlying tension the analyses of these different artists share in common is between the universalist assumptions of aesthetic modernism that underwrote the public image of the international touring soloist and the engagements of the soloists themselves with the vernacular movement vocabularies and subcultures they encountered, fostered, collected, participated in, reflected, and/or, ultimately returned to or abjured.

In "Dancing Greek Antiquity in Private and Public: Isadora Duncan's Early Patronage in Paris," Samuel N. Dorf considers the influence of American and French lesbian patronage and spectatorship on Duncan's idea of Greece in Paris between 1903 and 1908. Dorf shows that Duncan's Hellenism had to be to some degree inflected by Parisian Sapphism, and he reveals that the erotic connotations of Greek dance in Paris at this time were not limited to these semi-private performances in which Duncan participated, but were also largely present in the Opéra Comique through such figures as Regina Bardet. This article does not discuss Duncan's dances themselves so much as what was said about them in the milieu of Natalie Clifford Barney, the Princesse de Polignac, the Comptesse Elisabeth de Greffuhle, and Eva Palmer among others. Dorf explores what is at stake in the expunging of eroticism and exoticism from Duncan's image and returns us to its cultural history of reception.

Michelle Clayton's “Touring History: Tórtola Valencia Between Europe and the Americas” brings into focus a less than iconic figure today who was nonetheless a celebrated international soloist of her time. Clayton brings Valencia back from the margins of history by pointing to her very contemporary sensibility for intercultural exchange in the work she created and performed while on tour in South America between 1908 and 1930. While "the incarnation of a modernist cosmopolitanism" in Clayton's terms, Valencia collected costumes and art objects in her travels for which she created new choreography that brought an ethnographic and archaeological dimension to danced performance as a sort of living museum. Clayton favors the concept of mimetic mirroring over appropriation. Furthermore, as a collector of pre-Columbian art, Valencia actually exerted an influence on the preservation of Peruvian art.

Jennifer Fischer's “The Swan Brand: Reframing the Legacy of Anna Pavlova” makes parallel claims for Anna Pavlova in her touring between 1910 and 1925. Fischer analyzes the limitations of Pavlova's image — so well crafted that it accedes to the notoriety of a brand in modern advertising

\author{
(1)
}


parlance - to examine the ballet dancer's missionary brief in spreading ballet but also her interest in traditional dance, notably in India. The extraordinarily successful promotion of Pavlova as "the swan" has obscured our understanding of the complexity of her contribution to dance and dance history. Fischer adumbrates in particular an argument about the innovative potential of Pavlova's own choreography, a quality for which her work is not generally recognized, when it enters into contact with an indigenous culture.

Prarthana Purkayastha's "Dancing Otherness: Nationalism, Transnationalism, and the Work of Uday Shankar" reverses the pattern discerned in the first three articles by studying the reception of Uday Shankar in southern India in the 1930s. As Shankar returned home from his great successes on tours of Europe and America, a significant national critique of his use of Indian classic dance arose that has escaped critical examination by historians. Purkayastha posits Shankar's "otherness" with respect to the national cultural revival movement that began in 1932. With a focus on the Uday Shankar India Culture Centre, at Almora, and his film, Kalpana (1948), the author depicts Shankar as a "migrant artist" with respect to south Asian cultural nationalism. Here, the concept of transnationalism becomes useful in an era that precedes the theorization of this term, and is particularly relevant to the artist's activity as a filmmaker.

In this issue, we introduce the review essay format that will appear from time to time as a means to take on issues of contemporary critical theory that go beyond the straightforward book review. In connection with its self-consciously critical dimension, the book André Lepecki discusses, Dance Discourses, comes from a conference supported by the Centre National de la Danse in Cannes. The southern location drew more scholars from Spain and Italy than earlier CND conferences, and Susanna Franco and Marina Nordera published the book in Italian before it appeared in English. The first Dance Studies conference in Spain took place in Valladolid in 2008, and the Proceedings were published by Cecilia Nocilli and Alessandro Pontremoli in 2010. As I write this, I have received an e-mail about the Andrew W. Mellon Grant for "Dance Studies in/and the Humanities" awarded to Northwestern, Brown, and Stanford Universities to fund international postdoctoral fellowships. DRJ's move to Cambridge University Press and the journal's growing translation program are related positive developments.

Mark Franko

Editor, Dance Research Journal 